\section{Latin American Thyroid Society recommendations for the management of thyroid nodules}

\author{
Recomendações da Sociedade Latino-Americana \\ de Tireoide no manejo de nódulos tireoideos
}

Rosalinda Camargo', Sandro Corigliano ${ }^{2}$, Celso Friguglietti ${ }^{3}$, Alicia Gauna ${ }^{4}$, Rubén Harach ${ }^{5}$, Fernando Munizaga ${ }^{6}$, Hugo Niepomniszcze ${ }^{7}$, Fabian Pitoia ${ }^{7}$, Eduardo Pretell ${ }^{2}$, Mario Vaisman ${ }^{8}$, Laura Sterian Ward ${ }^{9}$, Nelson Wohllk ${ }^{6}$, Eduardo Tomimori'

\begin{abstract}
Several guidelines on diagnosis and treatment of thyroid nodules and cancer have recently been published. However, recommended practices are not always appropriate to different settings or countries. The aim of this consensus was to develop Clinical Guidelines for evaluation and management of patients with thyroid nodules applicable to Latin American countries. The panel was composed by 13 members of the Latin American Thyroid Society involved with research and management of thyroid nodules and cancer from different medical centers in Latin America. The consensus was produced based on the expert opinion of the panel with use of principles of evidence-based medicine. Following a group meeting, a first draft based on the expert opinion of the panel was elaborated and later circulated among panel members for further revision. After revision, this document was submitted to all LATS members for commentaries and considerations and finally revised and refined by the authors. The final recommendations represent state of the art on management of thyroid nodules applied to all Latin American countries. Arq Bras Endocrinol Metab. 2009;53(9):1167-75

Keywords

Thyroid nodule; thyroid ultrasonography; thyroid aspiration biopsy; radioactive iodine therapy
\end{abstract}

\section{RESUMO}

Vários consensos têm sido publicados acerca do diagnóstico e do tratamento de nódulos e câncer da tireoide. Entretanto, as recentes recomendações nem sempre são apropriadas para diferentes regiões ou países. 0 objetivo deste trabalho foi oferecer uma série de recomendações para a avaliação e conduta de pacientes portadores de nódulos tireoideos aplicáveis a todos os países da América Latina. 0 trabalho foi realizado por um comitê composto por 13 membros da Sociedade Latino-Americana de Tireoide envolvidos com pesquisa e manejo de pacientes portadores de nódulos e carcinoma diferenciado da tireoide, de diferentes centros médicos da América Latina. As recomendações foram estabelecidas, após consenso, utilizando as opiniões especializadas de cada membro e os princípios da medicina baseada em evidência. Após a primeira reunião do grupo, um primeiro documento foi elaborado e encaminhado a todos os membros para revisão. Posteriormente, o documento foi enviado aos membros da Sociedade Latino-Americana deTireoide para avaliação, sugestões e comentários. A versão final, elaborada após refinada revisão de todos os autores, representa o estado da arte no diagnóstico e na conduta de nódulos tireoideos, aplicáveis a todos os países da América Latina. Arq Bras Endocrinol Metab. 2009;53(9):1167-75

Descritores

Nódulo da glândula tireoide; ultrassonografia da tireoide; citologia aspirativa da tireoide; radioiodoterapia
${ }^{1}$ Faculdade de Medicina da Universidade de São Paulo, São Paulo, SP, Brasil ${ }^{2}$ Cayetano Heredia Peruvian University, Lima, Peru ${ }^{3}$ Faculdade de Medicina da Universidade de Santo Amaro (Unisa), São Paulo, SP, Brasil

${ }^{4}$ Ramos Meija Hospital, Buenos Aires, Argentina 5 "Dr. A. Oñativia" Hospital, Salta, Argentina

${ }^{6}$ University of Chile, Santiago, Chile ${ }^{7}$ University of Buenos Aires,

Buenos Aires, Argentina

${ }^{8}$ Universidade Federal do

Rio de Janeiro (UFRJ), Rio de Janeiro, RJ, Brasil

${ }^{9}$ Faculdade de Ciências Médicas, Universidade Estadual de Campinas (Unicamp), Campinas, SP, Brasil

Correspondence to: Rosalinda Camargo Rua Mirassol, 216, ap. 82 04044-010 - São Paulo, SP, Brasil ryasato@uol.com.br

Received on Mar/16/2009 Accepted on Oct/10/2009 


\section{INTRODUCTION}

It is estimated that around $10 \%$ of adults have palpable thyroid nodules. The overall incidence and clinical features of these nodules is influenced by age and level of iodine intake, with a particularly high incidence seen in iodine deficient areas $(1,2)$. The major objective in the evaluation of a nodule is the exclusion of malignancy. The risk of malignancy in a thyroid nodule varies between $5 \%$ and $10 \%$ in iodine-sufficient countries, and the amount of iodine supplemented in table salt can influence this incidence (3).

Programs of table salt iodination in many Latin American countries have produced important variations in iodine intake over the past few decades, and the impact of these changes on the behavior of thyroid nodules and cancer is still largely unknown (4). New imaging technologies, especially ultrasonography (US), have improved the sensitivity for detection of thyroid cancer, which is now often found incidentally on imaging studies performed for other indications. This has led to the identification of many patients with microscopic papillary thyroid cancers mostly without clinical significance $(5,6)$.

A set of recommendations for evaluation and management of patients with thyroid nodules has been developed in consensus by 13 members of the Latin American Thyroid Society (LATS). This panel was composed by individuals involved in research and management of thyroid nodules and cancer from distinct reference medical centers in Latin America to reflect different practice patterns. A first questionnaire assessing the most important issues on the subject was first discussed among panel members and a draft document based on the expert opinion of the panel's participants as well as on previously published information, was elaborated and circulated among panel members for further revision. This document was subsequently sent to all LATS members for comments and discussion and, finally, revised and refined in consensus by panel members. These final recommendations aim to represent the state of the art on thyroid nodule management applied to Latin American countries.

\section{DIAGNOSIS AND MANAGEMENT OF THYROID NODULES}

The widespread use of cross-sectional imaging and the large availability of neck US have improved the sensitivity for detection of thyroid lesions and contributed to an increasing number of patients diagnosed with nonpalpable thyroid nodules. These incidentally discovered nodules share a similar risk of malignancy with palpable nodules of similar size. In general, only nodules larger than $1 \mathrm{~cm}$ should be evaluated with diagnostic tests, since malignant nodules $\geq 1 \mathrm{~cm}$ have more aggressive clinical and histopathological characteristics compared with smaller ones. A strong association between cancer size and aggressiveness has been clearly demonstrated in patients with large papillary carcinomas and the relative risk of cancer-related death is reported to increase 1.4-fold for each $1 \mathrm{~cm}$ increment in tumor size (7).

Also, a progressive increase in recurrence and causespecific death rates has been reported in patients with malignant lesions progressing in size from $<1 \mathrm{~cm}$ to $1-4 \mathrm{~cm}$ and $>4 \mathrm{~cm}(8,9)$. Rossi and cols. (10) have reported that patients with cancers between 1.1 and $2 \mathrm{~cm}$ have a higher prevalence of extrathyroidal invasion, lymph node metastases and distant metastases at diagnosis compared with those with tumors of smaller size. The recurrence rate for these patients is almost threefold higher compared with patients with malignant tumors measuring $\mathrm{l} \mathrm{cm}$ or less. The group with larger cancers in this study had more aggressive clinical and histopathological characteristics than those with size smaller than $1.1 \mathrm{~cm} \mathrm{(10).}$

The panel recommends that thyroid nodules larger than $1 \mathrm{~cm}$ should be evaluated with diagnostic tests.

\section{History and physical examination}

All patients with thyroid nodules should be evaluated with complete history and physical examination with attention focused on the neck. Most thyroid carcinomas are silent and do not show any peculiar clinical or anamnestic feature. Rapid nodular growth, hoarseness, presence of palpable cervical lymph nodes, vocal cord paralysis, and fixation of the nodule to surrounding tissues are suggestive signs of malignancy. Patients with thyroid nodules and history of total body irradiation for bone marrow transplantation or head and neck irradiation are at higher risk for malignancy (11). A family history of a first-degree relative with thyroid cancer should be carefully assessed, considering the occurrence of familial non-medullary thyroid cancer (12).

\section{Laboratory evaluation}

Serum thyroid stimulating hormone (TSH) should be determined at the initial evaluation in all patients pre- 
senting with thyroid nodule. This test is very useful in identifying subtle thyroid dysfunction due to the high sensitivity of the TSH assay. If TSH levels are found to be outside the normal range, further investigation with measurement of thyroid peroxidase antibodies and free thyroxine (FT4) levels should be conducted. Serum thyroglobulin $(\mathrm{Tg})$ is not a sensitive tool to determine the etiology of thyroid nodules; therefore, measurement of $\mathrm{Tg}$ should not be routinely performed (13).

Although many studies have recommended measurement of calcitonin levels in patients with thyroid nodules for exclusion of medullary thyroid cancer, the cost-effectiveness of this investigation is still unclear. However, serum calcitonin measurement is warranted when there is family history of medullary thyroid cancer, multiple endocrine neoplasia type 2 (MEN 2) or pheochromocytoma. Levels above $100 \mathrm{pg} / \mathrm{mL}$ are highly suggestive of medullary carcinoma $(14,15)$.

The panel recommends TSH determination at the initial evaluation in all patients presenting with thyroid nodule. The panel also recommends calcitonin measurement if family history suggests medullary thyroid cancer.

\section{Thyroid ultrasonography}

Thyroid US is very accurate and sensitive for detection of thyroid nodules, although its ability to differentiate benign and malignant tumors is somewhat limited. This method measures the dimensions of nodules with great precision, identifies characteristics of the nodule, and evaluates diffuse parenchymal changes. It is noninvasive, relatively inexpensive, and able to identify nonpalpable nodules and nodules that are not detected by isotope scanning or other imaging techniques. Both 7.5 and $12 \mathrm{MHz}$ linear transducers accurately detect and measure thyroid nodules and are adequate to perform ultrasound-guided fine-needle aspiration biopsy (US-FNAB). These transducers are also acceptable for postoperative lymph node surveillance in patients with thyroid cancer.

Thyroid US should be performed in patients with palpable solitary nodules, multinodular goiter, history of external neck irradiation, and history of familial thyroid cancer or MEN 2 for detection of non-palpable nodules. However, due to its high sensitivity and relatively low specificity, thyroid US should not be used as a screening test in the general population. In patients with a solitary nodule or with few well-separated nodules, each nodule should be thoroughly described. The report should include a description of the position that each nodule occupies within the thyroid, the threedimensional measurements (longitudinal, anteroposterior and laterolateral), echotexture (solid, mixed, cystic or cystic with projecting solid mural mass), echogenicity (anechoic, isoechoic, hypoechoic, or hyperechoic), characteristics of the margins, presence of peripheral halo, presence of internal calcifications (micro or macrocalcifications) and presence of cervical lymph node enlargement.

When multiple nodules are found, a detailed description should be given of the nodules bearing ultrasonographic features associated with malignancy: hypoechogenicity in solid nodules, microcalcifications and irregular margins. In this case, care should be taken to avoid describing only the largest nodule (16-18).

The characteristics of the margins of the nodule and the echogenicity, or the nodular shape and the echogenicity have been shown to be suitable criteria to suggest the pathological diagnosis. The best compromise between the risk of missing carcinomas of potential clinical aggressiveness and the need to avoid unnecessary procedures is probably to use FNAB on nodules with at least one of the following components: microcalcifications, blurred margins, or hypoechoic pattern $(19,20)$.

Color and power Doppler sonography have been widely evaluated as diagnostic tools for detecting thyroid cancer. Many studies have observed that neoplastic nodules (adenomas and carcinomas) contain intranodular flow signals while the majority of the colloid nodules are either avascular or have halo flow signals only (21-23).

In contrast, other studies have reported that certain characteristics on Doppler US including vascular pattern, resistive index (RI) and maximal systolic velocity (MSV) are not useful parameters for distinguishing malignant from benign solid nodules (24-26). These characteristics, therefore, should not be used as diagnostic tools to determine which nodules should undergo FNAB (27).

The panel recommends US examination in all patients with suspected thyroid nodules, multinodular goiter, history of external neck irradiation, and history of familial thyroid cancer or MEN 2. In the opinion of the panel, nodular characteristics on color Doppler alone, including vascular pattern, RI and MSV values, are not useful parameters for distinguishing malignant from benign thyroid nodules. 


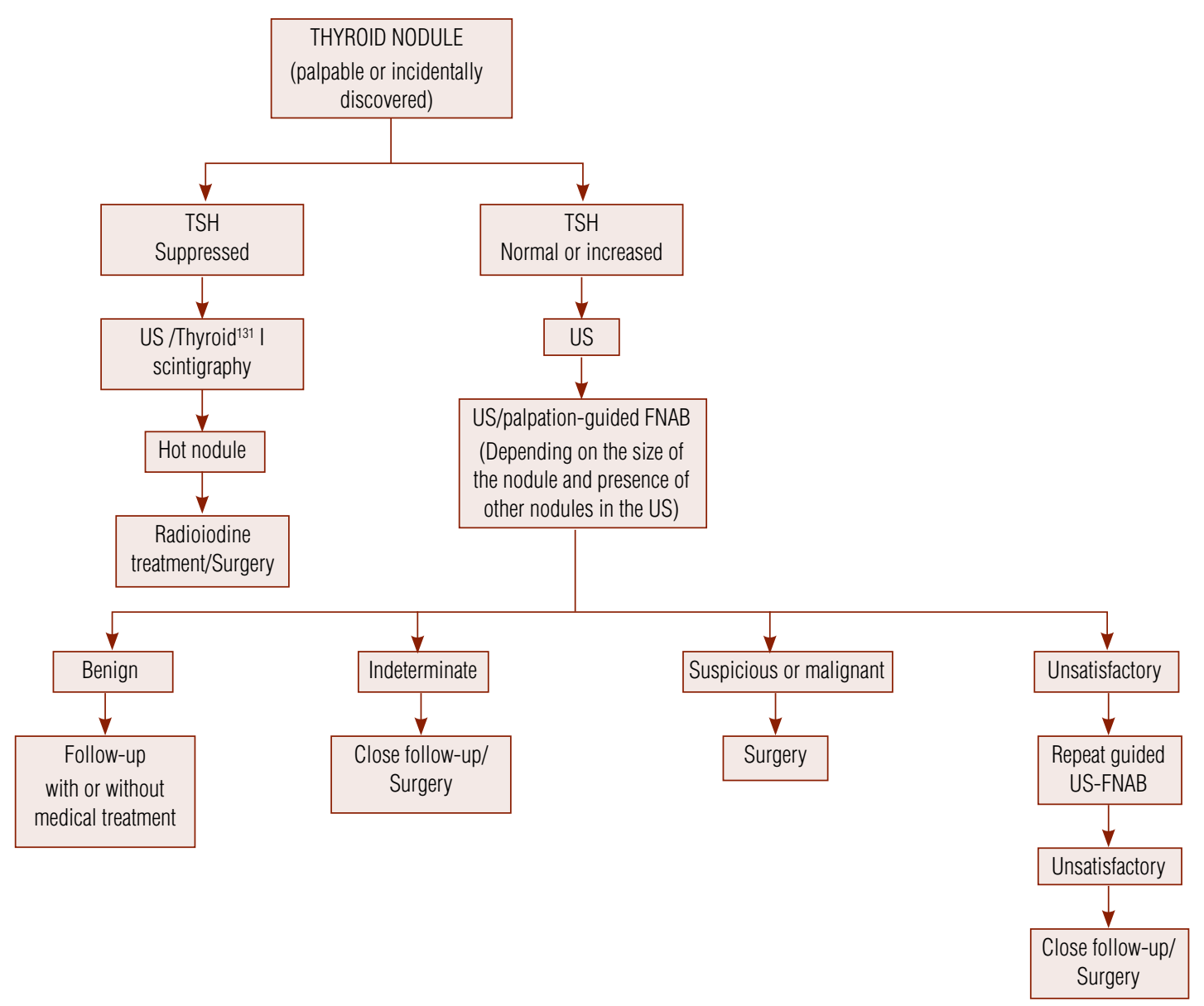

Figure 1. Algorithm for diagnosis and management of palpable and incidentally discovered thyroid nodules.

\section{Scintigraphy}

Thyroid scintigraphy should be performed in patients with single thyroid nodules and suppressed TSH, or in those with large toxic or nontoxic multinodular goiter (28).

\section{Other imaging techniques}

Magnetic resonance imaging (MRI), positron emission tomography (PET) with 18-fluorodeoxyglucose (FDG) and computed tomography (CT) are not recommended for routine examination of thyroid nodules, although, in some cases, non-contrast CT and MRI may add information to anatomic visualization not provided by US or radiography (29). Non-contrast CT may be indicated for large multinodular goiters that appear to extend into the upper mediastinum, particularly in elderly subjects.

Routine use of other imaging studies (PET, CT and MRI) is not recommended.

\section{Fine-needle aspiration biopsy (FNAB)}

All solid and solitary nodules $\geq 1 \mathrm{~cm}$ should be evaluated with FNAB. The procedure may be performed by free hand in palpable nodules, providing other nodules $>1 \mathrm{~cm}$ have been excluded by US.

US-FNAB is recommended in non-palpable nodules and in nodules with cystic changes. It allows a more precise and adequate sampling and is associated with a lower rate of false-negative results, thus improving global diagnostic accuracy in the preoperative selection of thyroid cancer (30).

Nodules $<1 \mathrm{~cm}$ may be followed yearly by US only. In case there is US evidence of growth, extracapsular invasion or presence of suspicious cervical lymph nodes, the nodule should also be evaluated by US-FNAB. Patients with a family history of medullary carcinoma or MEN 2 should also be evaluated with US-FNAB.

In a multinodular gland in which autonomous nodules have been detected on scintigraphy, US-FNAB should be considered for iso- or hypofunctioning no- 
dules. In this case, the choice of nodules to be aspirated should rely on suspicious US characteristics rather than size. Those with suspicious US features should be biopsied, preferentially.

All solid and solitary nodules $\geq 1 \mathrm{~cm}$ should be evaluated with FNAB. Nodules $<1 \mathrm{~cm}$ should be evaluated by fine-needle aspiration biopsy (FNAB) only in patients with history of familial thyroid cancer, MEN 2, cervical irradiation during childhood, or suspicious ultrasound findings. In a multinodular gland, nodules with suspicious US features should be preferentially biopsied.

\section{CYTOLOGICAL CLASSIFICATION OF THYROID NODULES}

The accuracy of thyroid aspiration cytology, a procedure which depends largely on the experience of the cytopathologist, may vary among different centers and even within the same institution (31).

The panel recommends that aspirates be interpreted by experienced cytopathologists according to the following cytological criteria:

\section{Benign}

- Colloid nodules: aspirates with abundant colloid, sheets and follicular groupings of cells with regular small nuclei.

- Hyperplasia within a nodular goiter: sheets and follicular groupings of cells with regular nuclei and scant colloid.

- Lymphocytic thyroiditis: abundant lymphocytes are present and may vary in size from normal, small lymphocytes to larger, activated lymphocytes.

\section{Indeterminate (follicular pattern)}

- Follicular neoplasms (follicular and oncocytic cell).

- Occasional hyperplastic or adenomatoid nodules within a multinodular goiter in which a microfollicular focus has been sampled by chance.

The smear patterns of hypercellular adenomatous nodules, microfollicular adenoma, follicular carcinoma and follicular variant of papillary carcinoma overlap. Cytopathology includes aspirates with high-to-moderate cellularity with hypertrophic regular non-atypical nuclei and presence of microfollicular pattern, with or without oncocytic (Hürthle) cell change and scant colloid.

\section{Suspicious for malignancy}

- Suspicious for papillary carcinoma: aspirates of moderate-to-high cellularity and equivocal features of malignancy, such as enlarged and irregular nuclei, occasional presence of nuclear folds but no cytoplasmic inclusions.

- Suspicious for follicular carcinoma: it includes also aspirates with microfollicular cytology with nuclear atypia and follicular oncocytic cells tumors. The diagnosis Hürthle-cell neoplasm/ follicular neoplasm with oncocytic features carries a higher risk of malignancy as compared with a diagnosis of follicular lesion/neoplasm (32).

\section{Malignant}

- Papillary carcinoma and variants: includes aspirates with high cellularity and cytologically malignant cells, tumor cells arranged in sheets, follicular and papillary architecture, and nuclear abnormalities such as intranuclear cytoplasmic inclusions and grooves.

- Medullary carcinoma: characterized by tumor cells that are notably non-cohesive and polymorphic (e.g., plasmacytoid, angular), and nuclei that are hyperchromatic, located at one pole of the cell and, eventually, with cytoplasmic inclusions.

- Poorly differentiated and anaplastic carcinomas: it includes aspirates with insular pattern; cells of anaplastic carcinoma are usually large and bizarre.

\section{Unsatisfactory}

Cases of limited cellularity or poor preservation and fixation. A specimen is qualified as satisfactory if presenting at least six to eight groups of well-preserved follicular cells with ten or more cells per group. The acceptable prevalence of unsatisfactory cytologies varies between $10 \%$ to $15 \%$.

Routine repeat biopsy is not recommended for nodules diagnosed as benign on FNAB; however, it may be considered if there is clinical or US evidence of nodular growth (> 20\% increase in volume) or if the nodule presents recurrent cystic degeneration.

\section{THERAPY}

\section{Suppressive therapy}

Despite the lack of beneficial evidence for suppressive therapy with levothyroxine (L-T4) or triiodothyronine 
$\left(\mathrm{T}_{3}\right)$ in decreasing the size of benign thyroid nodules, this treatment is used by some centers based on individual experience. Therapy with L-T4 may be helpful in preventing the development of novel nodules in the contralateral lobe or the development of goiter after lobectomy for follicular adenomas (33). Suppressive therapy is contraindicated in autonomous thyroid nodules, older patients and in those in whom suppression with L-T4 may present a potential hazardous risk - particularly patients with bone or cardiovascular disease.

The panel does not recommend suppressive therapy with L-T4 or T3 for benign nodules.

\section{Percutaneous ethanol injection}

There is limited experience on the treatment of solid thyroid nodules with percutaneous ethanol injection (PEI). However, some reports have shown encouraging results (34). This method has been used with acceptable results in patients with toxic adenomas (35). The panel does not recommend PEI for routine treatment of thyroid nodules other than cysts.

\section{Radioiodine treatment of nodular goiter}

Radioiodine therapy has been used for treatment of multinodular goiter in patients unsuitable for surgical treatment since the late 1980's. According to some studies, the decrease in goiter size induced by radioiodine can reach up to $40 \%(36-41)$. It is considered an alternative therapy for elderly patients with large goiters and/or at risk for surgery.

The use of rhTSH to increase radioiodine uptake and obtain a more uniform isotope distribution within the goiter has been considered over the past decade (42). Several doses of rhTSH have been tested yielding similar results, with an average reduction in gland size of $40 \%$ to $50 \%$ over 6 to 12 months $(43-47)$. New studies are necessary to address the adequate rhTSH dose and the correct radioiodine dose to obtain the best results with lowest adverse events (thyrotoxicosis, goiter enlargement or local pain).

The panel considers the radioiodine treatment of nodular goiter as an alternative therapy for patients with large goiters.

\section{Surgery}

Surgery should be performed in patients with malignant or clinically concerning nodules with suspicious or indeterminate cytology, in recurrent cystic nodules, and when there are esthetic, compressive symptoms or follow-up concerns (48).

Surgical options include lobectomy plus isthmectomy for solitary benign thyroid nodules and total thyroidectomy for multinodular goiters, suspicious and malignant nodules.

\section{Experimental therapies}

It has been recently described that higher circulating levels of insulin may cause increased thyroid proliferation and the formation of nodules (49). Insulin resistance syndrome has also been implicated as an important factor for cell proliferation $(50,51)$. Metformin treatment is associated with significant improvement of insulin resistance and could be another therapeutic tool in patients with thyroid nodules and insulin resistance.

Interstitial laser thermal ablation and percutaneous radiofrequency thermal ablation are new nonsurgical therapeutic options for benign thyroid nodules. Both methods induce nodule shrinkage and improvement in local symptoms $(52,53)$.

All these therapies are still experimental and their indications still need to be defined.

\section{Follow-up}

Follow-up of patients with thyroid nodule should be performed every 12 months with clinical and US examinations to reassess the size of the nodule. Nodules that present with growth, defined by an increase in volume $>20 \%$ or of $15 \%$ to $20 \%$ in the greater diameter by US examination performed with the same equipment (54) should be reevaluated by FNAB, considering that a first FNAB evaluation carries a $5 \%$ possibility of false negativity $(55,56)$. In case the size of the nodule remains unchanged after three assessments, the follow-up interval may be prolonged.

Benign thyroid nodules should be followed with serial ultrasound examination at 12- to 18-month intervals.

\section{THYROID NODULES IN CHILDREN}

The occurrence of thyroid nodules is uncommon in children and adolescents compared with adults, but when present, carry a higher risk of malignancy (14\% to $40 \%$ in children compared with $5 \%$ in adults) (57-60).

The effectiveness of FNAB in children is similar to that observed in adults, suggesting that FNAB may be equally effective in selecting younger patients for surgery with low risk of missing malignant lesions (61-64). 
All thyroid nodules $>0.5 \mathrm{~cm}$ in children must be evaluated with FNAB. The diagnostic steps for thyroid nodules in children and adolescents are similar to those for adults.

In children and adolescents, L-T4 therapy for benign nodules has some benefits, but efficacy is fairly low. Recent guidelines have addressed L-T4 therapy for small thyroid nodules diagnosed as benign on FNAB in children and adolescents. In considering L-T4 treatment, complete TSH suppression $(<0.1 \mathrm{mU} / \mathrm{L})$ should be avoided. Usually, there is nodular regrowth after discontinuation of L-T4; however, if this occurs during L-T4 treatment another FNAB and surgery should be considered (65).

Thyroidectomy for benign nodules (usually restricted to lobectomy) remains the most effective treatment modality for this group of patients. This is also true for cystic thyroid nodules in childhood (66).

The diagnostic and therapeutic approach to thyroid nodules in children should be the same as in adults.

\section{THYROID NODULES DURING PREGNANCY}

Between $11 \%$ and $15 \%$ of women develop new thyroid nodules during pregnancy. In areas of mild iodine insufficiency, preexisting nodules tend to increase in size during this period. The prevalence of thyroid nodules is significantly higher in women who have been pregnant compared with those with no previous pregnancies.

The diagnostic approach of a thyroid nodule discovered during pregnancy is similar to that in non-pregnant patients. However, most pregnant patients with a newly discovered thyroid nodule can safely undergo diagnostic studies as well as therapy after delivery when surgery can be performed without risk to the fetus (67). Exceptions to this rule are rapidly growing nodules and patients with extreme anxiety. The decision to operate during pregnancy should take into consideration the patient's attitude about forestalling treatment until postpartum as well as concerns about fetal risk. If the ultimate decision is to perform surgery during pregnancy, it should be avoided during the first and third trimesters, but rather, be performed during the second trimester (before fetal viability) which appears to be safer for both the patient and the fetus.

In all pregnant patients with thyroid nodules, thyroid function tests should be performed for detection of hypo- or hyperthyroidism. Thyroid ultrasound is a useful tool to characterize and monitor growth of thyroid lesions, detect thyroiditis and delineate the presence of suspicious lymph nodes in these patients. Radionuclide scanning of the thyroid is contraindicated during this period.

The panel recommends that the diagnosis and treatment of thyroid nodule that occurs during pregnancy be delayed until after delivery in most patients.

Acknowledgments: we gratefully acknowledge the contributions of Cristiane Almeida; Denise Wittmann; Geraldo Medeiros-Neto; Hector Perinetti; Luiz Kowalski; Marcos Tavares; Marilia Marone; Milena Braga-Basaria; Nilton Hanaoka; Nilton Herter; Rui Maciel; Sergio Toledo; and Suemi Marui.

Disclosure: Sandro Corigliano works as a clinical investigator for Takeda, GlaxoSmithKline, Merck Sharp Dohme, and Novartis Advisory Board for Sanofi-Aventis, and Merck Sharp Dohme; and as local speaker for GlaxoSmithKline, Merck Sharp Dohme, Sanofi-Aventis, and Abbott. Fabian Pitoia works as a consultant and speaker bureau Genzyme Corp. The others authors have no competing financial interests.

\section{REFERENCES}

1. Villena J, Pretell E. Bocio nodular tóxico en pacientes de zonas yodo deficientes y de la costa. Rev Méd Hered. 1991;2(4):149-55.

2. Villena J, Ferrufino JC, Klinge G. Nódulo tireoideo frio. Características clínicas y anatomopatológicas en pacientes migrantes de zonas con deficiencia de yodo y de la costa. Rev Méd Hered. 1993;4(4):188-93.

3. Harach HR, Ceballos GA. Thyroid cancer, thyroiditis and dietary iodine: a review based on the Salta, Argentina model. Endocr Pathol. 2008;19(4):209-20.

4. Pretell EA, Delange F, Hostalek U, Corigliano S, Barreda L, Higa $A M$, et al. lodine nutrition improves in Latin America. Thyroid. 2004;14(8):595-604.

5. Harach HR, Franssila KO, Wasenius VM. Occult papillary carcinoma of the thyroid. A "normal" finding in Finland. A systematic autopsy study. Cancer 1985;56(3):531-38.

6. Rosai J, LiVolsi VA, Sobrinho-Simoes M, Williams ED. Renaming papillary microcarcinoma of the thyroid gland: The Porto proposal. Int J Surg Pathol. 2003;11(4):249-51.

7. Hay ID, Grant CS, van Heerden JA, Goellner JR, Ebersold JR, Bergstralh EJ. Papillary thyroid microcarcinoma: a study of 535 cases observed in a 50-year period. Surgery. 1992;112(6):1139-46.

8. Jukkola A, Bloigu R, Ebeling T, Salmela P, Blanco G. Prognostic factors in differentiated thyroid carcinomas and their implications for current staging classifications. Endocr Relat Cancer. 2004;11(3):571-9.

9. Passler C, Scheuba C, Prager G, Kaczirek K, Kaserer K, Zettinig G, et al. Prognostic factors of papillary and follicular thyroid cancer: differences in an iodine-replete endemic goiter region. Endocr Relat Cancer. 2004;11(1):131-9.

10. Rossi R, Roti E, Trasforini G, Pansini G, Cavazzini L, Zatelli MC, et al. Differentiated thyroid cancers $11-20 \mathrm{~mm}$ in diameter have clinical and histopathologic characteristics suggesting higher aggressiveness than those $\leq 10 \mathrm{~mm}$. Thyroid. 2008;18(3):309-15.

11. Curtis RE, Rowlings PA, Deeg HJ, Shriner DA, Socie G, Travis LB, et al. Solid cancers after bone marrow transplantation. N Engl J Med. 1997;336(13):897-904. 
12. Sippel RS, Caron NR, Clark OH. An evidence-based approach to familial nonmedullary thyroid cancer: screening, clinical management, and follow-up. World J Surg. 2007;31(5):924-33.

13. Pacini F, Pinchera A, Giani C, Grasso L, Doveri F, Baschieri L. Serum thyroglobulin in thyroid carcinoma and other thyroid disorders. J Endocrinol Invest. 1980;3(3):283-92.

14. Niccoli P,Wion-Barbot N, Caron P, Henry JF, de Micco C, Saint Andre $\mathrm{JP}$, et al. Interest of routine measurement of serum calcitonin: study in a large series of thyroidectomized patients. The French Medullary Study Group. J Clin Endocrinol Metab. 1997;82(2):338-41.

15. Gagel RF, Hoff AO, Cote GJ. Medullary thyroid carcinoma. In: Lewis E, Robert D, Sidney H, Sidney C, (Eds). Werner and Ingbar's the thyroid: a fundamental and clinical text. Philadelphia: Lippincott Williams and Wilkins, 2005. p.967-88.

16. Papini E, Guglielmi R, Bianchini A, Crescenzi A, Taccogna S, Nardi $F$, et al. Risk of malignancy in nonpalpable thyroid nodules: predictive value of ultrasound and color-Doppler features. J Clin Endocrinol Metab. 2002;87(5):1941-6.

17. Camargo RY, Tomimori EK, Knobel M, Medeiros-Neto G. Preoperative assessment of thyroid nodules: role of ultrasonography and fine needle aspiration biopsy followed by cytology. Clinics. 2007;62(4):411-8.

18. Kang HW, No JH, Chung JH, Min YK, Lee MS, Lee MK, et al. Prevalence, clinical and ultrasonographic characteristics of thyroid incidentalomas. Thyroid. 2004;14(1):29-33.

19. Shimura $H$, Haraguchi $K$, Hiejima $Y$, Fukunari $N$, Fujimoto $Y$, Katagiri $\mathrm{M}$, et al. Distinct diagnostic criteria for ultrasonographic examination of papillary thyroid carcinoma: a multicenter study. Thyroid 2005;15(3):251-8.

20. Cappelli C, Castellano M, Pirola I, Cumetti D, Agosti B, Gandossi $\mathrm{E}$, et al. The predictive value of ultrasound findings in the management of thyroid nodules. QJM. 2007;100(1):29-35.

21. Holden A. The role of colour and duplex Doppler ultrasound in the assessment of thyroid nodules. Australas Radiol. 1995;39(4):343-9.

22. Papini E, Guglielmi R, Bianchini A, Crescenzi A, Taccogna S, Nardi $F$, et al. Risk of malignancy in nonpalpable thyroid nodules: predictive value of ultrasound and color-Doppler features. J Clin Endocrinol Metab. 2002;87(5):1941-6.

23. Chammas MC, Gerhard R, de Oliveira IR, Widman A, de Barros N, Durazzo $M$, et al.Thyroid nodules: evaluation with power Doppler and duplex Doppler ultrasound. Otolaryngol Head Neck Surg. 2005;132(6):874-82.

24. Frates MC, Benson CB, Doubilet PM, Cibas ES, Marqusee E. Can color Doppler sonography aid in the prediction of malignancy of thyroid nodules? J Ultrasound Med. 2003;22(2):127-31.

25. Rago T, Vitti P, Chiovato L, Mazzeo S, De Liperi A, Miccoli P, et al. Role of conventional ultrasonography and color flow-doppler sonography in predicting malignancy in 'cold' thyroid nodules. Eur J Endocrinol. 1998;138(1):41-6.

26. Lyshchik A, Moses R, Barnes SL, Higashi T, Asato R, Miga MI, et al. Quantitative analysis of tumor vascularity in benign and malignant solid thyroid nodules. J Ultrasound Med. 2007;26(6):837-46.

27. Tamsel S, Demirpolat G, Erdogan M, Nart D, Karadeniz M, Uluer $\mathrm{H}$, et al. Power Doppler US patterns of vascularity and spectral Doppler US parameters in predicting malignancy in thyroid nodules. Clin Radiol. 2007;62(3):245-51.

28. Pacini F, Burroni L, Ciuoli C, Di Cairano G, Guarino E. Management of thyroid nodules: a clinicopathological, evidence-based approach. Eur J Nucl Med Mol Imaging. 2004;31(10): 1443-9.

29. Kim TY, Kim WB, Ryu JS, Gong G, Hong SJ, Shong YK. 18F-fluorodeoxyglucose uptake in thyroid from positron emission tomogram (PET) for evaluation in cancer patients: high prevalence of malignancy in thyroid PET incidentaloma. Laryngoscope. 2005;115(6):1074-8.
30. Danese D, Sciacchitano S, Farsetti A, Andreoli M, Pontecorvi A. Diagnostic accuracy of conventional versus sonography-guided fine-needle aspiration biopsy of thyroid nodules. Thyroid. 1998;8(1):15-21.

31. De la Serna Saravia C, Cuellar F, Saravio Day E, Harach HR. Accuracy of aspiration cytology in thyroid cancer: a study in 1 institution. Acta Cytol. 2006;50(4):384-7.

32. Giorgadze T, Rossi ED, Fadda G, Gupta PK, Livolsi VA, Baloch Z. Does the fine-needle aspiration diagnosis of "Hurthle-cell neoplasm/follicular neoplasm with oncocytic features" denote increased risk of malignancy? Diagn Cytopathol. 2004;31(5):307-12

33. Niepomniszcze H, Garcia A, Faure E, Castellanos A, del Carmen Zalazar M, Bur G, et al. Long-term follow-up of contralateral lobe in patients hemithyroidectomized for solitary follicular adenoma. Clin Endocrinol (Oxf). 2001;55(4):509-13.

34. Alcantara-Jones DM, Araujo LM, Almeida AM, Jones DA, Cardoso LJ, Passos MC. Percutaneous ethanol injection for the treatment of thyroid nodules. Arq Bras Endocrinol Metabol. 2006;50(1):97-104.

35. Lippi F, Ferrari C, Manetti L, Rago T, Santini F, Monzani F, et al.Treatment of solitary autonomous thyroid nodules by percutaneous ethanol injection: results of an Italian multicenter study. The Multicenter Study Group. J Clin Endocrinol Metab. 1996;81(9):3261-4.

36. Hegedüs L, Hansen BM, Knudsen N, Hansen JM. Reduction of size of thyroid with radioactive iodine in multinodular non-toxic goitre. BMJ. 1988;297(6649):661-2.

37. Huysmans D, Hermus A, Edelbroek M, Barentsz J, Corstens F, Kloppenborg P. Radioiodine for nontoxic multinodular goiter. Thyroid. 1997;7(2):235-9.

38. Nygaard B, Hegedus L, Ulriksen P, Nielsen KG, Hansen JM. Radioiodine therapy for multinodular toxic goiter. Arch Intern Med. 1999;159(12):1364-8.

39. Huysmans DA, Hermus AR, Corstens FH, Barentsz JO, Kloppenborg PW. Large, compressive goiters treated with radioiodine. Ann Intern Med. 1994;121(10):757-62.

40. Nygaard B, Soes-Petersen U, Hoilund-Carlsen PF, Veje A, Holst PE, Vestergaard $A$, et al. Improvement of upper airway obstruction after 1311-treatment of multinodular nontoxic goiter evaluated by flow volume loop curves. J Endocrinol Invest. 1996;19(2):71-5.

41. Nygaard B, Faber J, Hegedus L. Acute changes in thyroid volume and function following 1311 therapy of multinodular goitre. Clin Endocrinol (Oxf). 1994;41(6):715-8.

42. Huysmans DA, Nieuwlaat WA, Erdtsieck RJ, Schellekens AP, Bus JW, Bravenboer B, et al. Administration of a single low dose of recombinant human thyrotropin significantly enhances thyroid radioiodide uptake in nontoxic nodular goiter. J Clin Endocrinol Metab. 2000;85(10):3592-6.

43. Nieuwlaat WA, Hermus AR, Sivro-Prndelj F, Corstens FH, Huysmans DA. Pretreatment with recombinant human TSH changes the regional distribution of radioiodine on thyroid scintigrams of nodular goiters. J Clin Endocrinol Metab. 2001;86(11):5330-6.

44. Nieuwlaat WA, Huysmans DA, van den Bosch HC, Sweep CG, Ross HA, Corstens FH, et al. Pretreatment with a single, low dose of recombinant human thyrotropin allows dose reduction of radioiodine therapy in patients with nodular goiter. J Clin Endocrinol Metab. 2003;88(7):3121-9.

45. Duick DS, Baskin HJ. Utility of recombinant human thyrotropin for augmentation of radioiodine uptake and treatment of nontoxic and toxic multinodular goiters. Endocr Pract. 2003;9(3):204-9.

46. Silva MN, Rubio IG, Romao R, Gebrin EM, Buchpiguel C, Tomimori $E$, et al. Administration of a single dose of recombinant human thyrotrophin enhances the efficacy of radioiodine treatment of large compressive multinodular goitres. Clin Endocrinol (Oxf). 2004;60(3):300-8. 
47. Albino CC, Mesa CO Jr, Olandoski M, Ueda CE, Woellner LC, Goedert CA, et al. Recombinant human thyrotropin as adjuvant in the treatment of multinodular goiters with radioiodine. J Clin Endocrinol Metab. 2005;90(5):2775-80.

48. Friguglietti CU, Lin CS, Kulcsar MA. Total thyroidectomy for benign thyroid disease. Laryngoscope. 2003;113(10):1820-6.

49. Rezzonico J, Rezzonico M, Pusiol E, Pitoia F, Neipomniszcze H. Introducing the thyroid gland as another victim of the insulin resistance syndrome. Thyroid 2008;18(4):461-4.

50. Vella v, Sciacca L, Pandini G, Mineo R, Squatrito S, Vigneri R, et al. The IGF system in thyroid cancer: new concepts. Mol Pathol. 2001;54(3):121-4.

51. Rezzonico J, Rezzonico M, Pusiol E, Pitoia F, Neipomniszcze H 2008 Metformin treatment of benign thyroid nodules in euthytoid patients with insulin resistance. Diabetes Vasc Dis Reas.2008; 5:223.

52. Papini E, Guglielmi R, Bizzarri G, Graziano F, Bianchini A, Brufani C, Pacella S, Valle D, Pacella CM. Treatment of benign cold thyroid nodules: a randomized clinical trial of percutaneous lases ablation versus levothyroxine therapy or follow-up. Thyroid. 2007;229-35.

53. Spiezia S, Garberoglio R, Milone F, Ramundo V, Caiazzo C, Assanti $A P$, et al. Thyroid nodules and related symptoms are stably controlled two years after radiofrequency thermal ablation. Thyroid. 2009;19(3):219-25.

54. Alexander EK, Hurwitz S, Heering JP, Benson CB, Frates MC, Doubilet PM, et al. Natural history of benign solid and cystic thyroid nodules. Ann Intern Med. 2003;138(4):315-8.

55. Carmeci C, Jeffrey RB, McDougall IR, Nowels KW, Weigel RJ UItrasound-guided fine-needle aspiration biopsy of thyroid masses. Thyroid. 1998;8(4):283-9.

56. Ylagan LR, Farkas T, Dehner LP. Fine needle aspiration of the thyroid: a cytohistologic correlation and study of discrepant cases. Thyroid. 2004;14(1):35-41.
57. Hung W, Anderson KD, Chandra RS, Kapur SP, Patterson K, Randolph JG, et al. Solitary thyroid nodules in 71 children and adolescents. J Pediatr Surg. 1992;27(11):1407-9.

58. Yip FW, ReeveTS, Poole AG, Delbridge L. Thyroid nodules in childhood and adolescence. Aust N Z J Surg 1994;64(10):676-8.

59. Hegedus L. Clinical practice. The thyroid nodule. N Engl J Med. 2004;351(17):1764-71.

60. Niedziela M. Pathogenesis, diagnosis and management of thyroid nodules in children. Endocr Relat Cancer. 2006;13(2):427-53.

61. Degnan BM, McClellan DR, Francis GL. An analysis of fine-needle aspiration biopsy of the thyroid in children and adolescents. $J$ Pediatr Surg. 1996;31(7):903-7.

62. Lugo-Vicente H, Ortiz VN, Irizarry H, Camps JI, Pagan V. Pediatric thyroid nodules: management in the era of fine needle aspiration. J Pediatr Surg. 1998;33(8):1302-5.

63. Corrias A, Einaudi S, Chiorboli E, Weber G, Crino A, Andreo M, et al. Accuracy of fine needle aspiration biopsy of thyroid nodules in detecting malignancy in childhood: comparison with conventional clinical, laboratory, and imaging approaches. J Clin Endocrinol Metab. 2001;86(10):4644-8.

64. Amrikachi M, Ponder TB, Wheeler TM, Smith D, Ramzy I. Thyroid fine-needle aspiration biopsy in children and adolescents: experience with 218 aspirates. Diagn Cytopathol. 2005;32(4):189-92.

65. Gharib H, Papini E, Valcavi R, Baskin HJ, Crescenzi A, Dottorini ME, Duick DS, Guglielmi R, Hamilton CR Jr, Zeiger MA, Zini M; AACE/AME Task Force on Thyroid Nodules. American Association of Clinical Endocrinologists and Associazione Medici Endocrinologi medical guidelines for clinical practice for the diagnosis and management of thyroid nodules. Endocr Pract. 2006;12(1):63-102.

66. Wiersinga WM. Management of thyroid nodules in children and adolescents. Hormones (Athens). 2007;6(3):194-9.

67. Moosa M, Mazzaferri EL. Outcome of differentiated thyroid cancer diagnosed in pregnant women. J Clin Endocrinol Metab. 1997;82(9):2862-6. 